\title{
LANDSLIDING IN \\ ALLEGHENY COUNTY, \\ PENNSYLVANIA
}

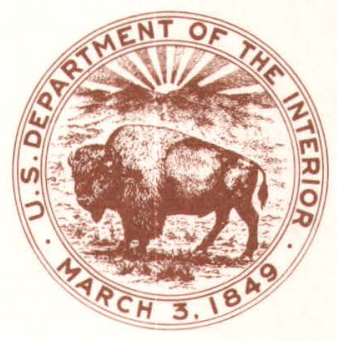

PREPARED IN COOPERATION WITH THE APPALACHIAN REGIONAL COMMISSION

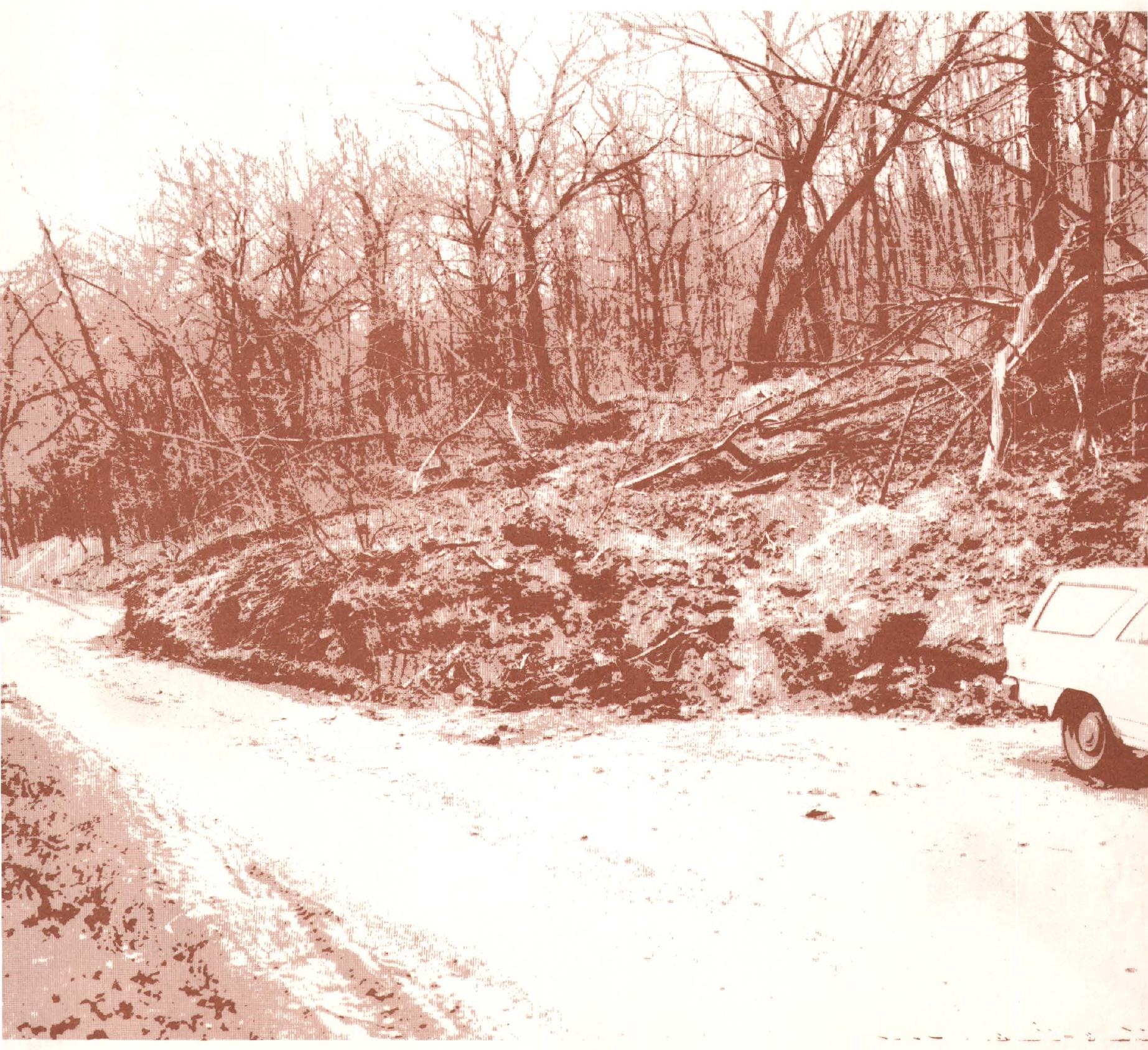





\title{
Landsliding in Allegheny County, Pennsylvania
}

\author{
By Reginald P. Briggs, John S. Pomeroy \\ and William E. Davies
}

GEOLOGICAL SURVEY CIRCULAR 728

Prepared in cooperation with

the Appalachian Regional Commission

To accompany Map of Susceptibility to

Landsliding, Allegheny County, Pennsylvania:

U.S. Geological Survey Miscellaneous Field

Studies Map MF-685B. 


\section{United States Department of the Interior THOMAS S. KLEPPE, Secretary}

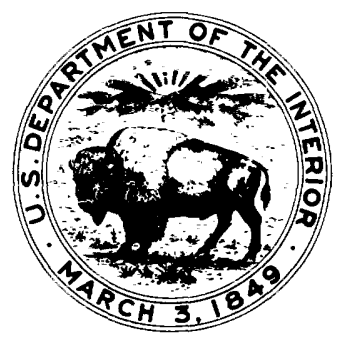

\section{Geological Survey V. E. McKelvey, Director}

Library of Congress Cataloging in Publication Data

Briggs, Reginald Peter, 1929-

Landsliding in Allegheny County, Pennsylvania.

(Geological Survey circular; 728) To accompany map of susceptibility to landsliding, Allegheny County, Pennsylvania: U.S. Geological Survey miscellaneous field studies map MF-685.B.

Bibliography: $p$.

Supt. of docs. no.: I 19.4/2:728

1. Landslides--Pennsylvania--Allegheny Co. I. Pomeroy, John S., 1929- joint author. II. Davies, William E., 1917- joint author. III. Appalachian Regional Commission. IV. Title. V. Series: United States. Geological Survey. Circular; 728.

QE75.C5 no. 728 [QE599.U5] 557.3 08s [551.3' 5' 3] 75-35786

Free on application to Branch of Distribution, U.S. Geological Survey, 1200 South Eads Street, Arlington, VA 22202. 


\section{CONTENTS}
Abstract
Introductio
Recommendations and advice for the nontechnical reader
taken only with caution
What the buyer, builder, or homeowner should look for -................
Geologic factors affecting susceptibility to landsliding in Allegheny County -...-
Selected landslide localities
Glossary
References cited
1
2
3
5
8
11
16
18

Page

age

\section{ILLUSTRATIONS}

Figure

1. Location of Allegheny County

2-7. Diagrams showing:

2. Landslide nomenclature

3. Slump

4. Earthflow

5. Rockfall

6. Debris slide

7. Creep

8-13. Photographs of:

8. Landslide largely in fill, Lawnwood Avenue

9. Earthflow on West Smithfield Road

10. Landslide on Painters Run

11. Landslide in Glenfield area

12. Pipeline path, Fallen Timber Run

13. Slumped area, Interstate 79

14. Map showing selected landslide localities

2

2

2

3

3

17. Photographs of:

15. Distressed concrete retaining wall, Baldwin Road

16. Toe of landslide, Kilbuck Drive

17. Landslide on Lawnwood Avenue 



\title{
Landsliding in Allegheny County, Pennsylvania
}

\author{
By Reginald P. Briggs, John S. Pomeroy, and William E. Davies
}

\begin{abstract}
Man should proceed with caution if modifications such as loading, excavation, or changes of the water regime are contemplated for slopes in Allegheny County, especially those slopes described on the map as highly sensitive to disturbance by man. Features indicative of unstable slope conditions include: cracks in buildings, yard walls, and pools; doors and windows that jam; fences and other linear features bowed out of line; tilted trees and utility poles; cracks and steplike ground features; hummocky ground; and water seeps. Geologic factors related to the landsliding process include rock types, layering, fracturing, and attitude; nature of soil cover; permeability of rocks and soils; and steepness of slope.
\end{abstract}

\section{INTRODUCTION}

Most scientific and technical workers familiar with slope-stability problems in Allegheny County (fig. 1) agree that man's modification of sensitive slopes causes more than 90 percent of the landsliding in the area. If man causes landslides, he also can control or prevent them, actively by engineering or passively by judicious land use.

A recent study of the county was made to define areas where a significant degree of suscepti-

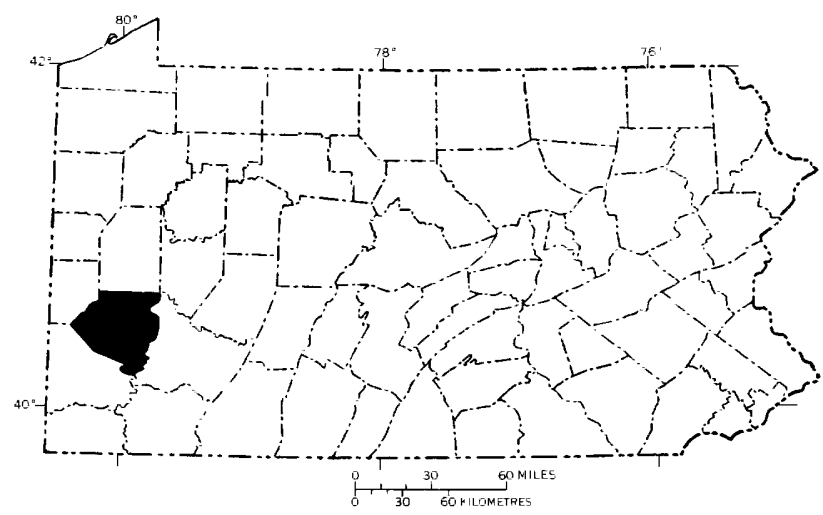

Figure 1.-County outline map of Pennsylvania showing location of Allegheny County (shaded). bility to landsliding can be expected and thus where special engineering attention or land-use control are most needed. This report chiefly is a supplement to the map by Pomeroy and Davies (1975), which is referred to herein as the companion map.

The report has two chief parts: (1) A discussion of landsliding causes and evidences of landsliding and (2) a discussion of geologic factors affecting landsliding, including brief descriptions of specific landslides. The geographic focus is Allegheny County, but advice and discussion also have application to adjacent parts of the Appalachian Plateaus.

The report and companion map were prepared as part of a larger program sponsored by the Appalachian Regional Commission, a frogram chiefly aimed at improved management of land resources in Allegheny County. In addition, the report and companion map are contributions to a U.S. Geological Survey environmental analysis of the Greater Pittsburgh region.

The writers benefitted from information and assistance freely given by many persons in County, State, and Federal governments and private firms. They are too many to cite individually, but their help is gratefully acknowledged. In addition, valuable information was obtained from previous reports on landsliding and related factors by Ackenheil (1954), Ackenheil and Associates (1968), Briggs (1974), Craft (1974), Fisher and others (1968), Gray (in Wagner and others, 1970 , p. 103-105), Hamel (1970, 1972), Hamel and Flint $(1969,1972)$, Kelley (1971), Myers (1935), Philbrick (1959, $1960)$, U.S. Soil Conservation Service (1973a, b), and Winters (1972). 


\section{RECOMMENDATIONS AND ADVICE FOR THE NONTECHNICAL READER}

Landslides affect many Allegheny County residents, in some places sporadically, and in others more or less constantly. Sometimes they pose a severe financial threat or they may be a minor but almost constant nuisance.

Figure 2 shows the general form of many landslides and gives nomenclature commonly used. Slump (fig. 3) is the prevalent type of landslide in Allegheny County. All prehistoric and many recent landslide deposits are largely the result of slumping. Earthflows (fig. 4) are common, and rockfalls (fig. 5) and debris slides (fig. 6) are rather frequent, particularly from highway and railroad cuts.

Most landslides actually are composites of two or more of these types, but usually a given landslide is labelled for the dominant type present. For example, a large slump may have rockfalls and debris slides at its head, and earthflows may occur at its base.

Rockfalls are the most rapid landslides, ranging in duration from a split second to a few seconds at most. Debris slides normally last from seconds to minutes, but if the source of debris is large, for example, a huge mine-refuse bank, a debris slide can move more or less continuously for hours. Duration of an earthflow depends largely on its size. Smaller earthflows can be finished in minutes, but most probably last for an hour or more. Slumps commonly move relatively slowly, forming in hours or even months; some slumps, however, can take place in minutes.

Soil creep is a gradual, more or less continu-

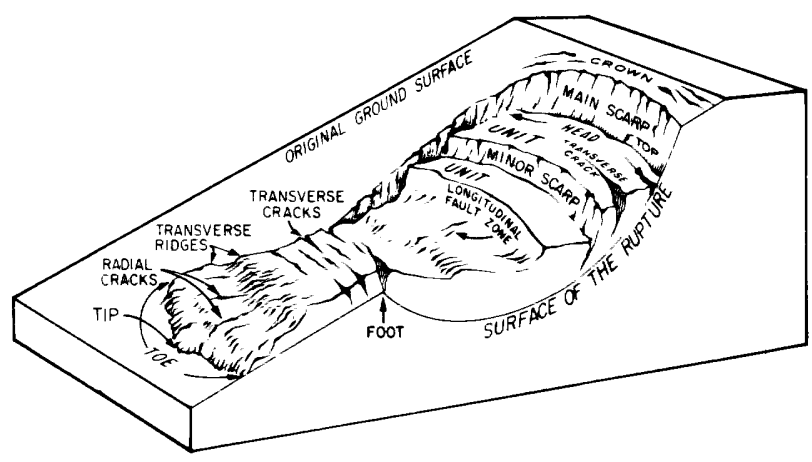

Figure 2.-Nomenclature of parts of a landslide (simplified from Eckel, 1958). ous downslope movement of soil (fig. 7), and usually is not considered a landslide process, but it can be accelerated into landsliding. The basic distinction is that an area of crep does not show significant ground breakage--no scarps or cracks.

Generally landslides in the county are slowmoving so there is ample time to avoid personal hazard; deaths and injuries are rexe. Rockfalls are the chief exception. In one place in adjacent Beaver County in 1942, 150 cubic yards of rock

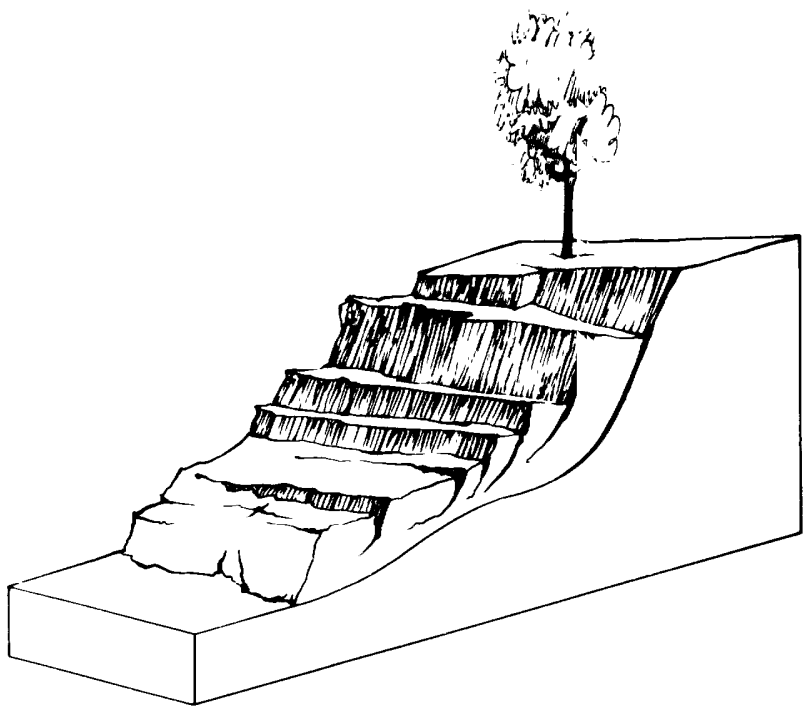

FIGURE 3.-Slump-coherent or intact masses that move downslope by rotational slip on surfacas that underlie and penetrate the landslide deposit (from Nilsen, 1972).

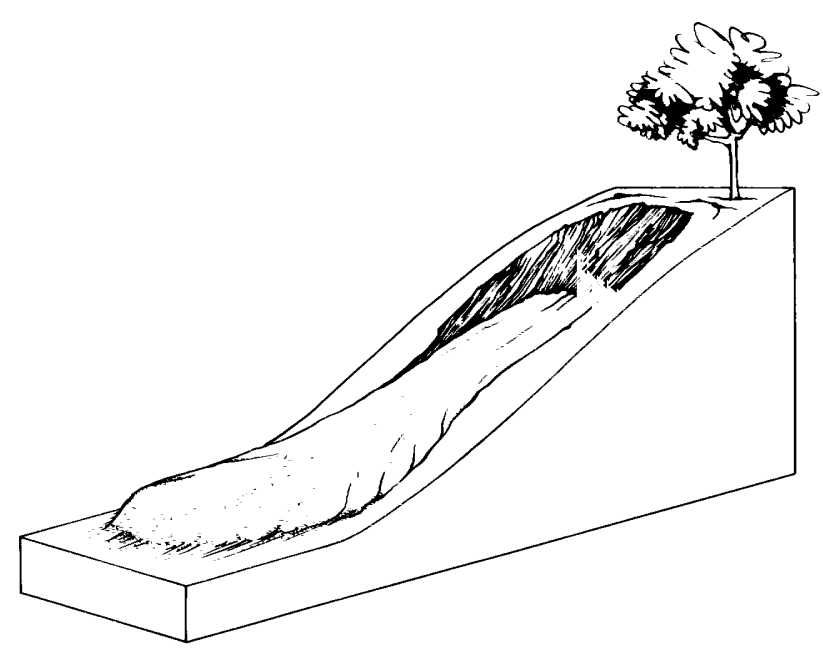

Figure 4.-Earthflow-colluvial or fill materials that move downslope as a viscous fluid, for example, thick syrup (from Nilsen, 1972). 


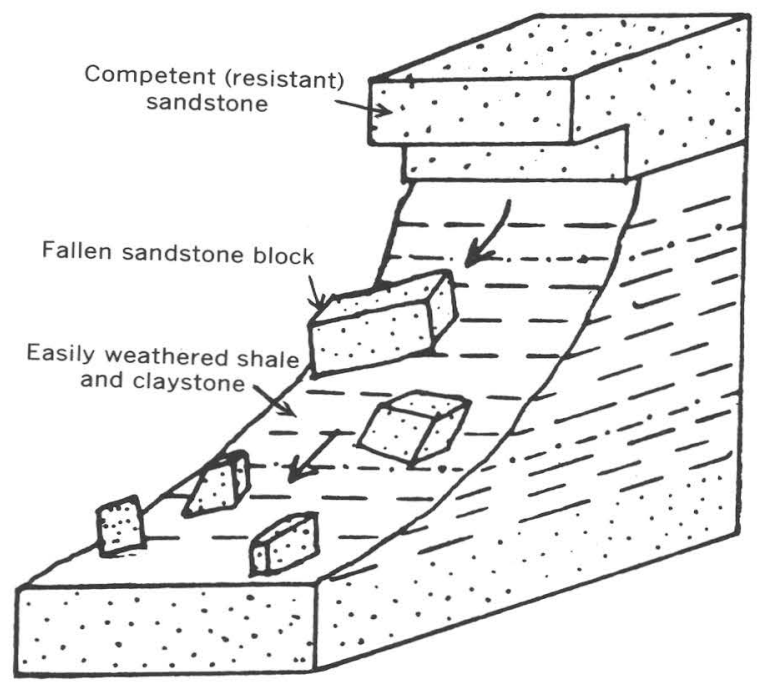

FIGURE 5.-Rockfall-rock masses that move primarily by falling through air (from Pomeroy, 1974).

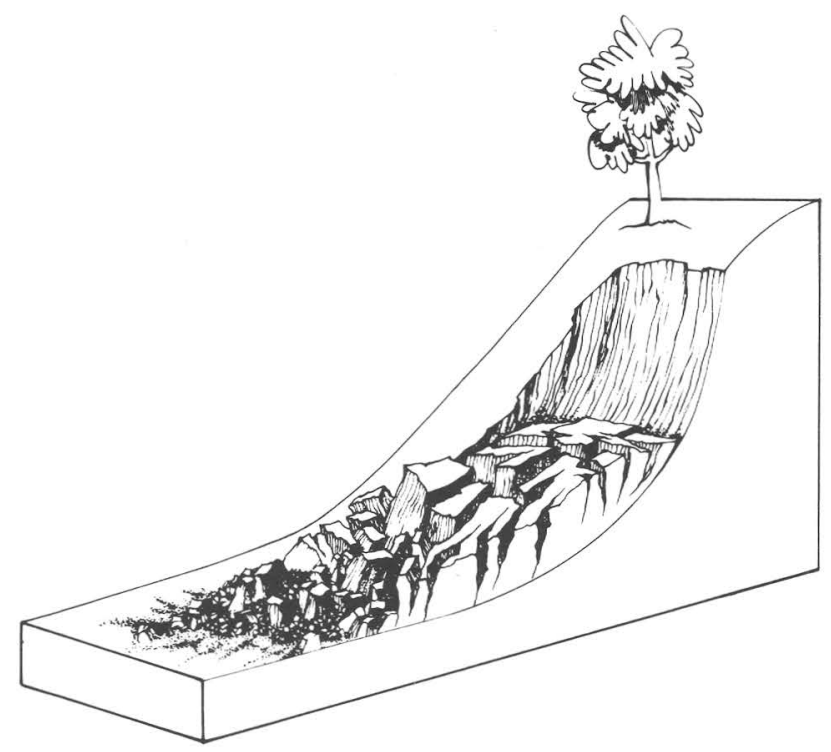

Figure 6.-Debris slide-incoherent or broken masses of rock and other debris that move downslope by sliding on a surface that underlies the deposit (from Nilsen, 1972).

fell and crushed a bus, killing 22 passengers and injuring four (Ackenheil, 1954).

Property damage ranges from very serious in relatively rare cases, such as the destruction of a dwelling, blockage of a transportation route, and destruction of a reservoir, to minor in very frequent cases, such as slumping at the edge of a lawn or highway shoulder. Thus few individual landslide events are extremely costly, although the Allegheny County Department of

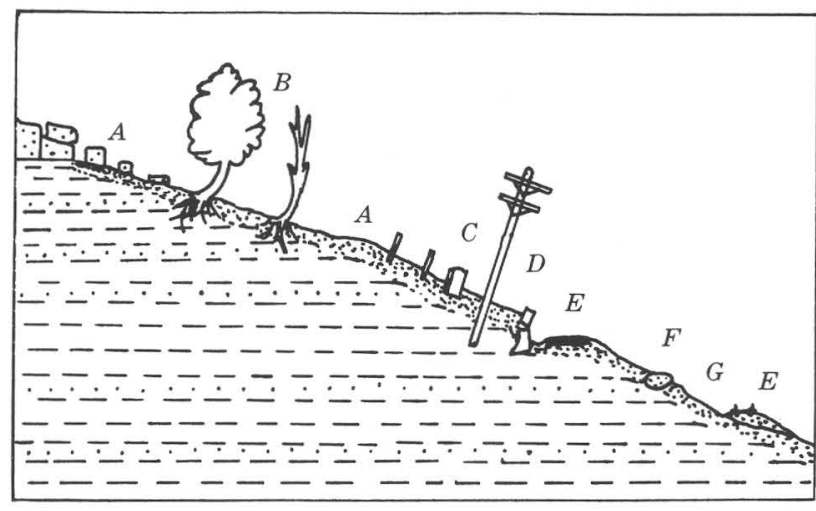

FiguRE 7.-Creep-Common evidence: $(A)$ moved blocks of rock; $(B)$ trees tilted at appreciable angles downslope with curved trunks concave upslope; $(C)$ displaced posts, poles, and monuments; $(D)$ broken or displaced retaining walls and foundations; $(E)$ roads and railroads moved out of alinement; $(F)$ turf rolls occurring downslope from creeping boulders; $(G)$ stone line near base of creeping soil (modified from Sharpe, 1938).

Planning and Development has estimated costs of damages from landsliding in the county from 1970 to 1974 at nearly 2 million dollars each year (W. C. Morrison, oral commun., 1974). Doubtless unreported, and so not included in this figure, are many events that may cost the individual homeowner perhaps 100 dollars for repair.

\section{ACTIONS TO BE AVOIDED OR TO BE TAKEN ONLY WITH CAUTION}

Most landslides in Allegheny County result from loading the tops or cutting into sensitive slopes, construction of fills on slopes, or altering water conditions of slopes. No significant actions should be taken without site investigations by competent technical personnel. Sketches in the margin of the companion map illustrate possible results from these actions. In the paragraphs below, the selected landslide localities referred to in parentheses are described later in this report and are located on the companion map.

Loading.-The most common loading (actually overloading) of a slope is by emplacing earth materials or slag as a fill, usually to extend the backyard of a house on the slope or on a ridgetop. Loading can cause the formation of surfaces of rupture in underlying soil and rock, 
resulting in failure. Structures also are loading factors. In most places they are set on bedrock, but when they are not, destruction may result -as occurred on Lawnwood Avenue (fig. 8; selected landslide locality 8 ).

Cutting into a slope.-Because valleys of the region are rather narrow, excavation of the foot of a slope to make more flat ground is very common. This can be disastrous, particularly if the cut is in the toe of an unidentified prehistoric landslide deposit, as happened during construction of Interstate 79 (selected landslide locality 2) and on West Smithfield Road (fig. 9; selected landslide locality 11).

Placing fills on slopes.-Proper construction of a fill on a slope involves engineering practice, and should be designed for the particular slope on which it is to be placed; it includes removal of natural vegetation before emplacement and lift-by-lift compaction. If vegetation is not removed, surfaces of rupture or slip planes can form on decaying vegetation between the new fill and the former natural slope; if fill is not compacted, failure can take place within it. The Painters Run (fig. 10) and Lawnwood Avenue (fig. 8) localities (selected landslide localities 5 and 8 , respectively) are examples of fill failure, as are many other residential and backyard fills in Allegheny County.

Altering water conditions.-Natural slopes largely are protected from excessive infiltration of water by their vegetation; removal of vegetation can increase infiltration and thus increase susceptibility to landsliding. Faulty drainage systems, such as inadequate disposal of downspout water, also can affect slopes. Alteration of

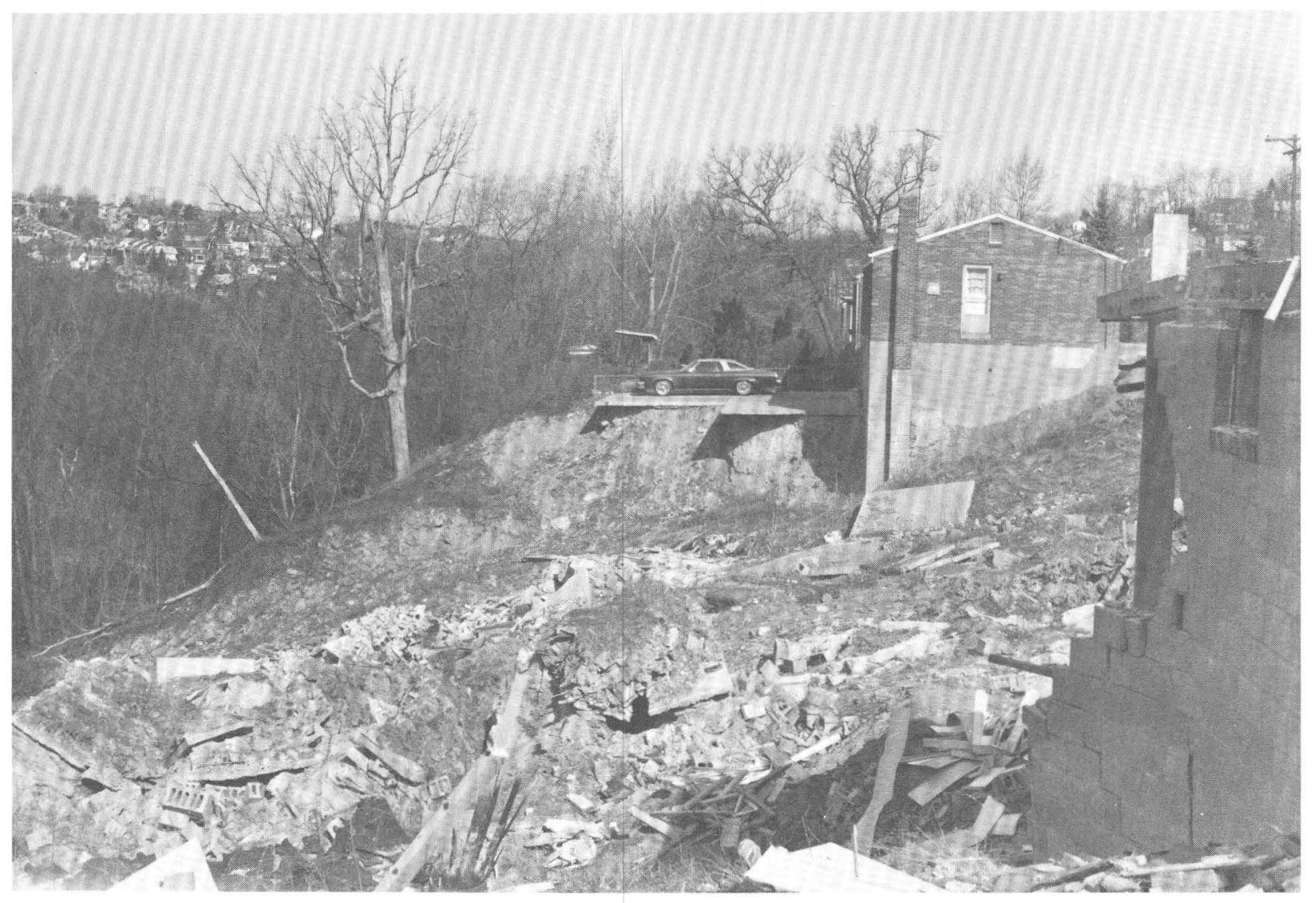

FIgURE 8.-Landslide largely in fill, Lawnwood Avenue, Brentwood and Baldwin Boroughs. Warped wall of partially dismantled house in right foreground results from movement of footings that were not set in bedrock. House in right background is set on bedrock and apparently is not distressed structurally even though side and backyards have slipped away. Note large trees inclined strongly downslope behind car and house, evidence of a history of movement in the area. Photographed in April 1975. 


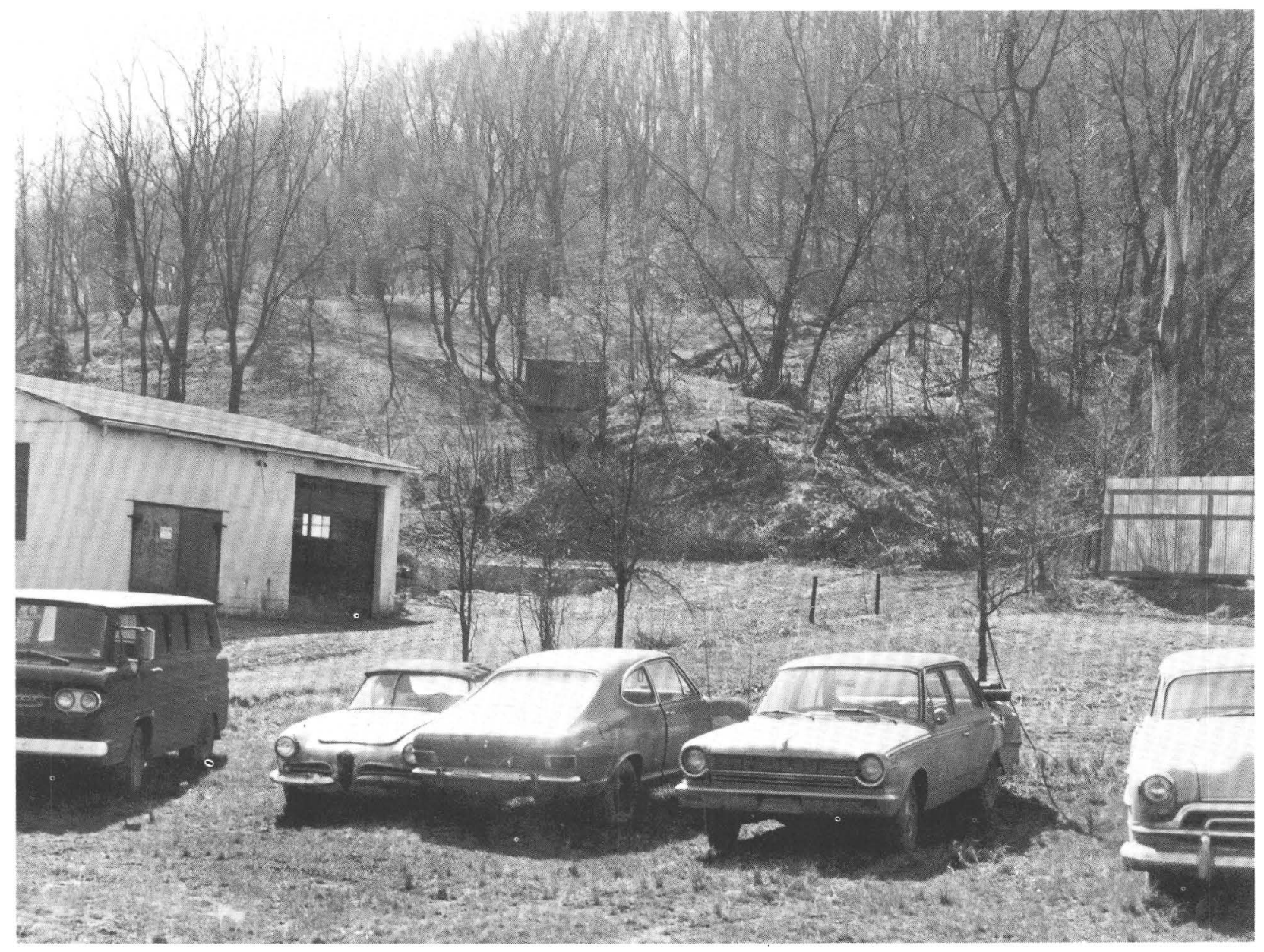

Figure 9.-Active earthflow on south side of West Smithfield Road, between locality 11 and Boston. Toe is visible at base of slope from just above second car from right to just above the small car. Head is more than 100 feet upslope. Excavation that triggered earthflow was to valley-floor level as far back as small shed on slope. Left limit of earthflow is just to the right of shed, which itself has not moved appreciably. Note tilted trees on earthflow surface, and hummocky ground typical of surfaces of prehistoric landslides on slope to left of shed. Photographed in April 1975.

water conditions may have been a factor in the Baldwin Road, Robinson Township slide (selected landslide locality 3 ).

\section{WHAT THE BUYER, BUILDER, OR HOMEOWNER SHOULD LOOK FOR}

The buyer, builder, or homeowner must always bear in mind that areas susceptible to landslides commonly are larger than most individual properties. Thus, it pays to look not only at the property in question but also at adjacent areas, particularly those upslope and downslope. If the property slopes more steeply than about 15 percent (15 feet of drop or rise vertically in 100 feet of horizontal distance), or if adjacent uphill or downhill slopes (or both) are significantly steeper than the slope of the property, site examinations should be made. In addition, if the property is on relatively flat ground on a ridge top or in a valley, but close to a fairly steep slope, an examination of the slope is recommended. It is most important to look for the features listed in areas labelled as highly sensitive on the companion map.

The following features are indications that a property may have a potential or real landslide problem. All the features listed have been associated with landsliding in Allegheny County. If any of these are observed, the buyer, builder, 


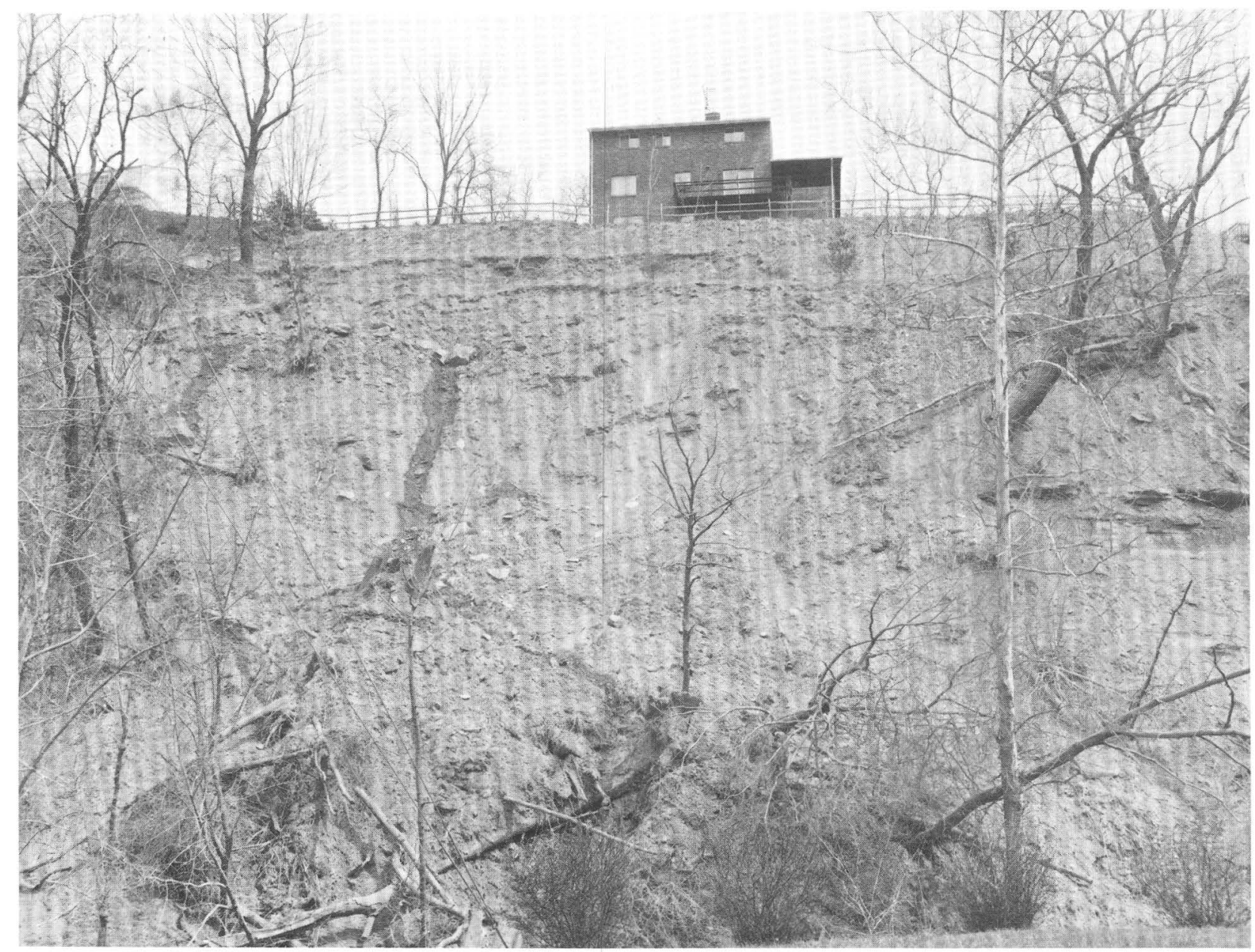

Figure 10.-Landslide on Painters Run, Upper St. Clair Township. Debris at foot of slope partially blocks the creek, which is between camera station and slope. Note seepage from slope in left center; nearly horizontal bedrock exposed at right. House is set on bedrock and apparently is not threatened structurally. Photographed in April 1975.

or owner should seek advice from competent technical personnel.

(1) Cracks in buildings.- Most older buildings have minor cracks, but these probably result largely from normal settlement. In general, the fact that a building is old and shows no significant damage is an indication that the building probably will remain undamaged by landsliding. Many or large cracks in newer structures are reasons for concern, although the cause of cracking may well be something other than landsliding. Major cracks commonly are repaired by owners, but evidence of repair usually is visible on close examination. Wet basements may be evidence of cracks in foundation.

(2) Cracks in brick walls around yards and other outside brick and concrete features.Unlike buildings, which generally are set in bedrock, most yard walls and other ancillary features rest on soil. They thus are sensitive to creep which can cause cracking or can pull such features away from structures.

(3) Doors and windows that jam.-A door that sticks or otherwise does not seem to fit well or a sash window that jams may be evidence that the frame of a house has been warped.

(4) Retaining walls, fences, curbs, gas meters, posts supporting porches, and other features out of plumb or not alined in a normal way.-Fences and similar features usually are vertical and straight when built, curbs normally are straight, and gas-meter piping generally is 
horizontal when installed. Leaning fence posts, bowed fence or curb lines, and other departures from the expected thus require explanation.

(5) Breakage of underground pipes and other utilities.-Downslope movement can upset the alinement of buried utilities. For example, a pipeline parallel to a slope can be bowed by compression or strained by tension and ultimate breakage can result. Evidence of breakage includes otherwise unexplained wet ground, lowered water or gas pressure, and failure of service.

(6) Leaky swimming and decorative pools.Concrete pools are rigid and tight when constructed. Soil movement can cause cracking, which creates an additional hazard in that water leaking from cracked pools can enter the ground and perhaps accelerate movement.
(7) Tilted trees, grapevines, reeds.-Trees are probably somewhat less reliable indicators of slope movement than are manmade objects, for trees on slopes tend to bend outward somewhat as they seek sunlight. However, trees leaning at appreciable angles (fig. 8) or numbers of trees leaning in different directions (fig. 9) strongly suggest areas of landsliding or strong creep. Many grapevines (fig. 11) and reeds have been observed on many prehistoric landslide deposits, perhaps as a result of water conditions within the deposits. They thus are general indicators of possible instability.

(8) Tilted utility poles and taut or sagging wires.-Most utility poles are more or less vertical and alined when new, and wires between poles usually sag uniformly, so appreciable tilting of poles and variations in amount of sag of

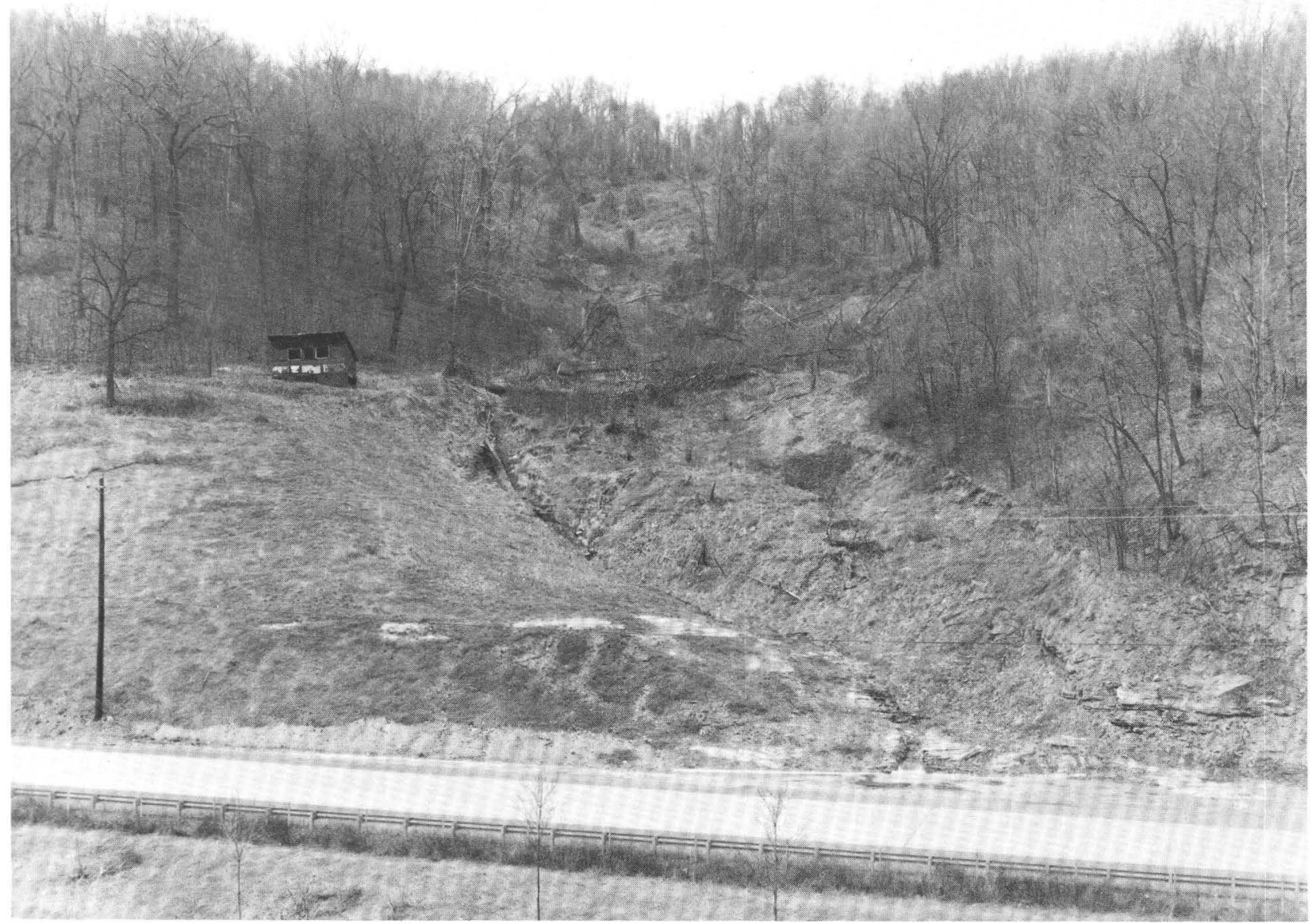

Figure 11.-Landslide on southeast-facing slope in Glenfield area extends almost from ridgetop to road. Note tilted and fallen trees on the landslide and grapevines on and adjacent to the landslide. Shed on left is on hummocky ground typical of surfaces of prehistoric landslide deposits. Relocation of the road in the foreground may have triggered the earthflow. Photographed from Interstate 79 in April 1975. 
wires between adjacent poles are abnormal and noteworthy.

(9) Cracks in the ground.-Cracks more or less parallel (across) to a slope usually are indications that the slope is moving. Unusually wide cracks are shown in figure 12.

(10) Steplike ground features.-Slumping of ground usually results in steplike scarps (fig. 2) that may range from very low to many feet high. When relatively new, the "risers" of the scarps usually expose fresh earth (fig. 13). Older scarps may have subdued angles because of erosion and may be vegetated, making them more difficult to identify. Whether old or new, these features are evidence of unstable conditions.

(11) Hummocky ground.-Hummocks, low mounds, are common irregularly spaced features of the toes and lower ground surfaces of both prehistoric and recent landslides (fig. 9; fig. 13). They do not occur naturally on any other surfaces in Allegheny County.

(12) Water seeps.--Seeps and springs are very common at the toes of landslide deposits. Water from seeps on upper slopes may saturate the ground and so contribute to the mobility of downslope materials (fig. 10). Swampy ground and small and perhaps short-lived areas of ponded water are common evidences of groundwater seepage on slopes.

\section{GEOLOGIC FACTORS AFFECTING SUSCEPTIBILITY TO LANDSLIDING IN ALLEGHENY COUNTY}

Bedrock in Allegheny County is entirely composed of coal-bearing rocks of Pennsylvanian and Permian age (between 320 and 225 million years ago). Formation names, from oldest to youngest, are the Freeport in the Allegheny Group, the Glenshaw and the Casselman in the

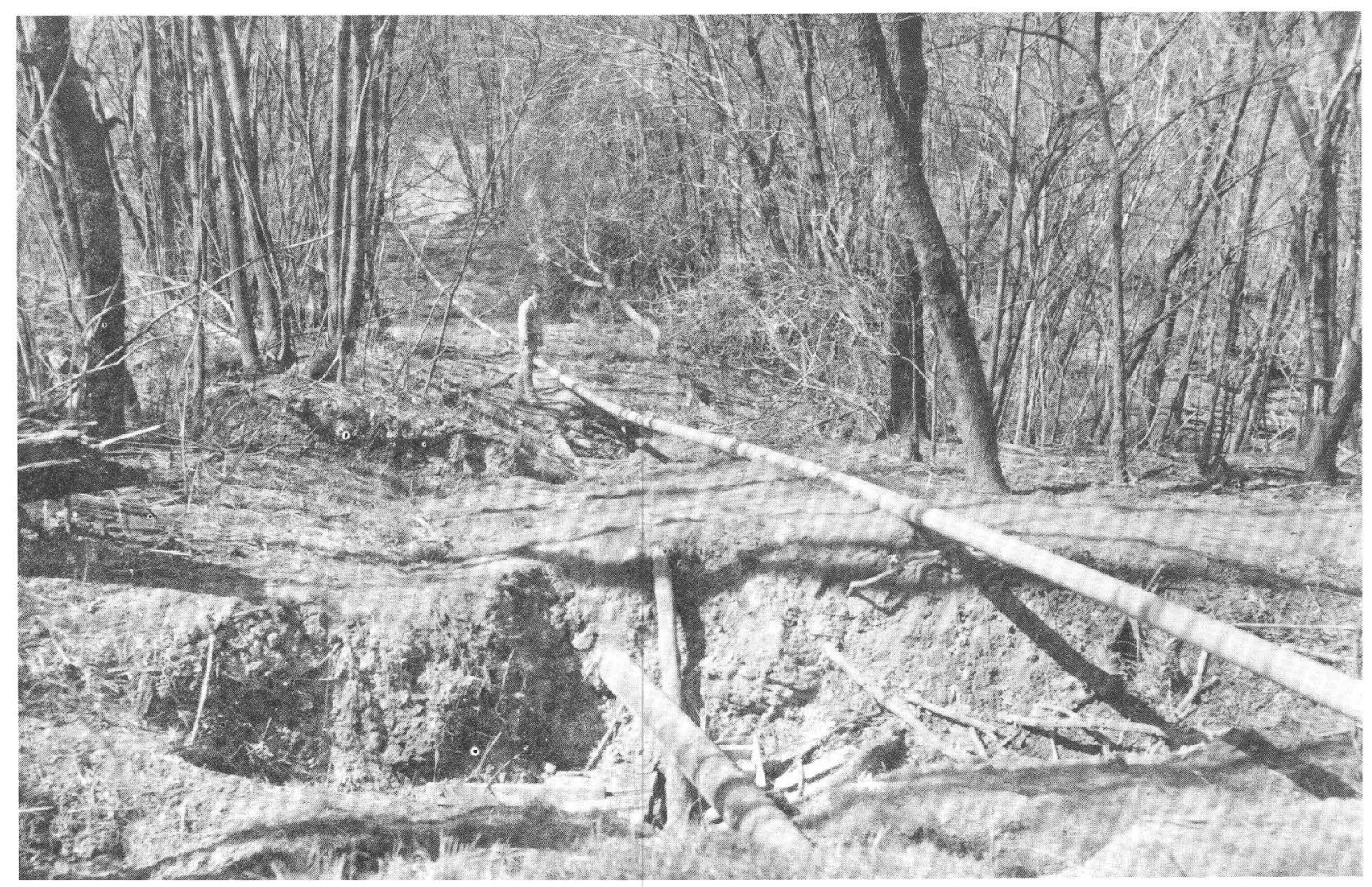

Figure 12,-View southwestward down cleared pipeline path toward Fallen Timber Run and Pennsylvania Highway 51, visible through trees. Ground cracks as much as 10 feet wide parallel across slope. Note segments of broken and abandoned pipe in foreground crack and in background crack near foot of man. Replacement pipe laid on surface. Photographed in April 1975. 
Conemaugh Group, the Pittsiburgh and the Uniontown in the Monongahela Group, and the Waynesburg and the Washington in the Dunkard Group. Their relations and general distribution are shown in the columnar section and small-scale geologic map that accompany the companion map. The reader is referred to "Geology of the Pittsburgh area" (Wagner and others, 1970) for a thorough description of the general geology.

Significant factors bearing on landslide susceptibility include:

(1) Rock types.-Rocks appearing at the surface are mostly sandstone, siltstone, shale, claystone, and limestone. Coal constitutes less than 2 percent of the rocks exposed in the area. Of particular significance to slope stability are widespread red beds, dusky red layers of claystone and shale, thickest and most consistent near the top of the Glenshaw Formation, but also common in the lower part of the Glenshaw and in the basal and upper middle parts of the Casselman Formation. Red beds also are present sporadically in the lower Pittsburgh Formation and other parts of the stratigraphic section. No sensitive red beds are known in the Freeport Formation. As shown on the companion map, landslides clearly are most common on deeply weathered red-bed slopes, but thick beds of gray to brown claystones in the Monongahela Group and the lower Washington Formation of the Dunkard Group also weather rapidly and underlie extensive areas where slopes are unstable. Sandstone and limestone commonly are harder and more resistant to weathering than are siltstone, claystone, and shale. This explains why sandstone and limestone form ledges and cliffs on many slopes, whereas other rock types rarely are well exposed except in cut banks of streams, in other very steep natural slopes, and in manmade exposures such as highway cuts. The distribution of rock types and their general engineering characteristics have been summarized by Kohl and Briggs (1975) on a map of Allegheny County at the same scale as the companion map.

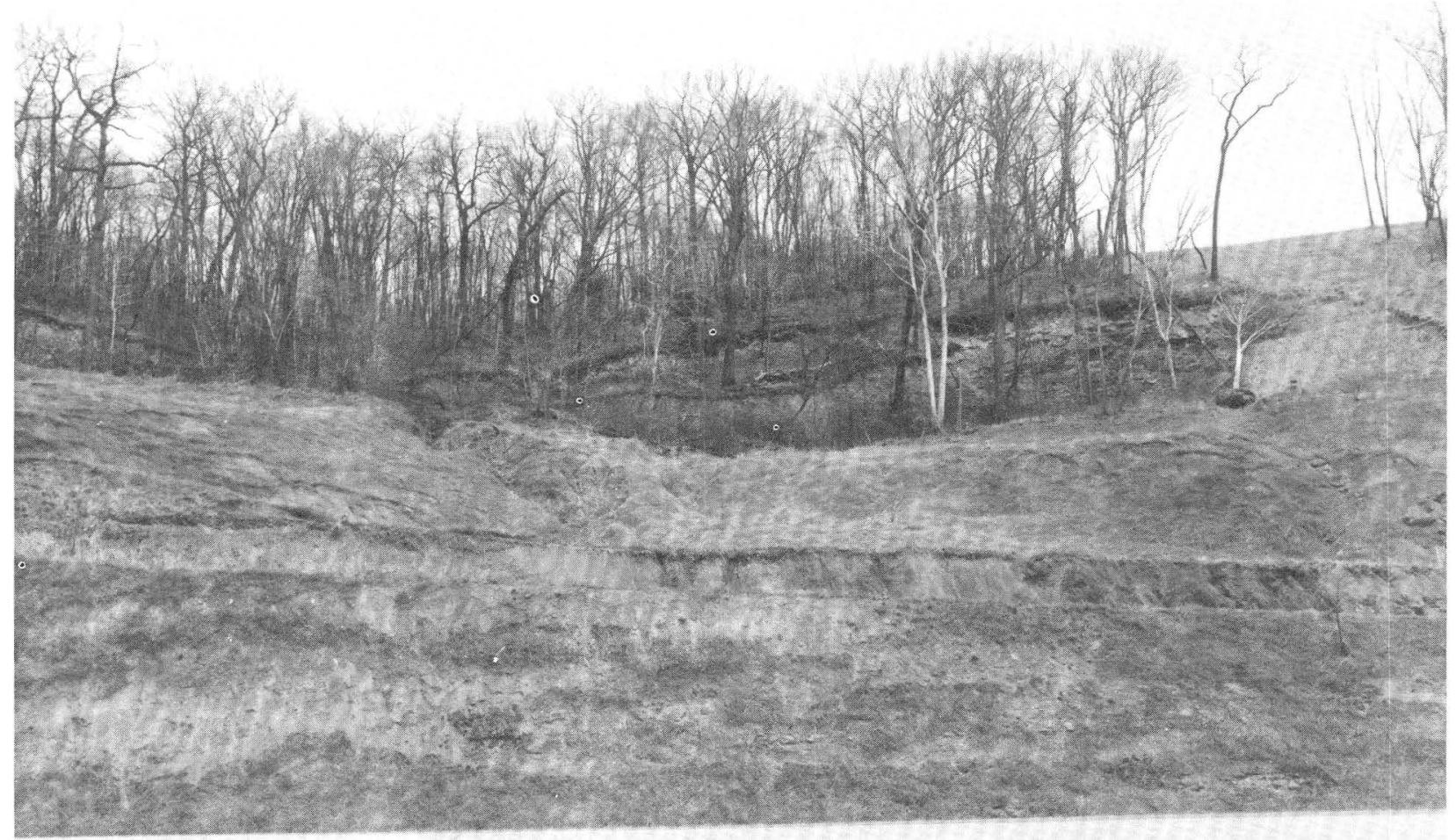

FIGURE 13.-Slumped area above northwest-facing roadcut for northbound lane of Interstate 79, Glenfield area. Scarps define slump blocks on which tilted trees are in contrast to upright trees on undisturbed slopes above. Note small scarps and hummocky ground below trees and above bench. Photographed in April 1975. 
(2) Rock layering.-Rock types alternate and form layers that are commonly 1 inch to 10 feet thick (fig. 10), but in places, layers are thicker than 30 feet. Some rock layers are traceable for miles, but most sandstone layers, for example, grade laterally into another rock type in short distances, and some conspicuous lateral changes in rock types can be seen in a single exposure. If, for example, a red-bed layer beneath a sandstone layer is decomposed by weathering, then the overlying hard rock is less firmly supported and may move downslope in response to gravity.

(3) Rock fractures.-Two types of rock fracture occur: faults-fractures along which rocks on one side are offset from rocks on the other side; and joints-tight to open fractures, along which no evidence of movement can be seen. Open joints are those in which rocks on either side are sufficiently far apart to allow relatively free passage of air or water. Along tight joints, rocks on either side are in close contact with each other. Faults are relatively rare in Allegheny County. The harder rock layers, composed of sandstone and limestone, are well jointed in outcrop, joints commonly being open and spaced one to several feet apart. Closely spaced joints occur in many siltstone, claystone, and shale layers, but most of these joints are tight. Most joints are nearly perpendicular to the plane of layering. Joints contribute to landslide susceptibility, for if rock layers were not jointed, their tendency to break off when underlying rock is removed would be less. Open joints are also an important factor in rock permeability.

(4) Attitude of rock layering.-Most rock layers in Allegheny County are tilted at such small angles from the horizontal that their attitude can best be measured in feet per mile rather than in degrees or in percent of grade (fig. 10). Rock attitude is most critical to landsliding on slopes where rock layers dip in the same general direction as the slopes but at lesser angles than the slopes, for on such overdip slopes, ground-water discharge is enhanced, and water is an important factor in most landslides (Briggs, 1974).

(5) Soil cover.-Soils are composed chiefly of fine-grained mineral constituents derived from rock decomposition during weathering. However, the term "soil" means different things to different people. To a soil scientist, soil means the material that supports plant life and that has undergone near-surface zonation resulting from the interaction of climate and living matter, conditioned by slope and relief. An agricultural soil rarely is more than 6 feet deep and may rest on and be developed from a parent material that is itself decomposed rock. To an engineer, soil includes all unconsolidated material above hard bedrock, and so includes the parent material of many agricultural soils. Only where depth to hard bedrock is relatively shallow will there be virtual agreement between a soil scientist and an engineer as to thickness and composition of a soil. "Soil" is used in this report in the engineering sense; it thus applies not only to material resulting from rock weathering in place, but also to masses of fragmented and decomposed rock particles that have been transported and redeposited elsewhere. Examples of transported soils are colluvium (soil accumulated at the base of slopes) and alluvial terrace deposits (deposited from running water). Both of these types can be subject to landsliding.

In Allegheny County, soils of the hilltops are relatively thin, less than 6 feet thick in many areas. Soils of hill slopes are absent where bedrock crops out, are relatively thin on many upper slopes, and are made up of more than 20 feet of colluvium on many lower slopes. Valleybottom soils generally have nearly level surfaces and so are not a significant factor in most landsliding; they may exceed 100 feet in thickness.

The composition of a soil reflects the composition of the rock from which the soil was derived, for sandstone will weather to a sandy soil, shale to a clayey soil, and hard blocky rocks may weather to a rocky soil. Most soils are loose to moderately cohesive and are finer grained near the surface than they are at depth. They will not stand long on steep slopes, and, in Allegheny County, soils weathered from red beds and, to a somewhat lesser extent, limestone are particularly sensitive to undercutting, overloading, or other processes. Clayey soils when dry commonly are crumbly and relatively low in weight per unit volume. When wetted, clay 
soils retain water and so become heavier, become plastic, and, depending on their mineral composition, may become very slippery. Many wet clayey soils resemble modeling clay in feel, relative weight, and plasticity.

(6) Permeability of rocks and soils.-Permeability as used here means the capacity of bedrock and soil to transmit water. Sandstone in the county commonly is moderately permeable; water may pass around grains of sand and through voids between the grains. In addition, sandstone layers may have open joints that facilitate passage of water. Limestone is fine grained, and solid unfractured limestone is more or less impermeable. However, most layers of limestone are permeable because they are closely jointed, and these joints commonly are open because of dissolution and removal of minerals by moving ground water. In contrast, siltstone and shale are fine grained and tightly jointed; they commonly are less permeable than most coarser grained rocks. Similarly, most sandy and rocky soils are more permeable than are soils composed largely or entirely of clay. Rocks and soils are most likely to be saturated by water in zones where permeable materials overlie relatively impermeable materials. Complete saturation commonly results in increased pore pressures that decrease cohesiveness between particles and increase buoyancy in the saturated material. The effect is similar to lubrication and enhances susceptibility to landsliding.

Permeability of rocks and soils and other facets of the shallow ground-water regime relevant to the landsliding process have been described in greater detail by Subitzky (1974a, b, c).

(7) Steepness of slopes.-Allegheny County is a land of hills and ridges separated by valleys through which streams and rivers flow at levels commonly 300 feet, and locally more than 600 feet, below adjacent ridge crests. The valley walls are relatively steep; slopes of 25 percent (25 feet of drop in 100 feet of horizontal distance; about $14^{\circ}$ ) or greater occupy about onefourth of the area. These steep natural slopes are leading factors in the occurrence of landslides, for if the area were largely one of relatively flat or gently sloping land surfaces, it is unlikely that even red beds would become in- volved in significant landsliding on natural slopes.

Relative importance of factors.-All the above stated factors are interrelated. At a given place, one factor may be the chief control of susceptibility to landsliding, whereas at another place, the same factor may be less important than others. For example, where a major stream is undercutting its bank by flowing against it, oversteepening will occur and slope failure ultimately will ensue regardless of whether the bank material is rock or soil ; where a thick soil cover becomes saturated with water, failure may occur even on relatively gentle slopes. Some slopes can be consistent landslide hazards because of natural or manmade steepness or excessive rock fracturing; some overdip slopes, on the other hand, may be less susceptible to landsliding because only one type of rock is present.

\section{SELECTED LANDSLIDE LOCALITIES}

Given below are brief descriptions of $\mathbf{1 5}$ localities that are examples of landsliding types and effects in Allegheny County. The companion map shows the localities by number; general locations are shown on figure 14. In addition, word descriptions are sufficient for location with the assistance of road maps of Pittsburgh and vicinity issued by oil companies. Included are some localities described in greater detail by others (chiefly Ackenheil, 1954), as well as localities identified during the current study.

(1) Sewickley Water Works area Nevin Avenue-Waterworks Road, Borough of Sewickley.-The base of a recent landslide on the south wall of the valley near the westernmost impoundment is at an altitude of $\mathbf{8 5 0}$ feet; its head is at approximately 950 feet with a scarp in red beds at the edge of an upper road. Waterworks personnel report that the slide took place in summer 1973 after heavy rains. A major factor in sliding appears to be infiltration of water from above into the landslide mass. Layers of red mudstone exposed above the scarp locally $\operatorname{dip} 15^{\circ} \mathrm{SW}$. and appear to be part of an older landslide deposit. The valley has many prehistoric landslide areas, and both sides of the valley have hummocky lower slopes and typically thick colluvial deposits. An older (1940) landslide on the north side of the valley just upstream from 
the same impoundment is a classic example of the effects of unusually heavy rainfall combined with man's modification of a sensitive slope. Loading of the red-bed slope with sandstone quarry waste was compounded by additional loading and an unusual degree of saturation owing to an unusually high amount of precipitation for the day of the event as well as for the previous week and month. As documented by Ackenheil (1954), the combined loading caused a landslide of an estimated 350,000 cubic yards that ruined one reservoir. The sandstone rubble overlying the affected slope is considerable. In winter, dense misty patches caused by warm-air exhalations into colder air demonstrate the existence of extensive interconnecting voids in the landslide mass.

(2) Interstate 79 (279), Glenfield area about 1 mile north of the Ohio River.-During earthwork for highway construction, prehistoric landslide masses in red beds were excavated. Oversteepening of slopes of these highly sensi-

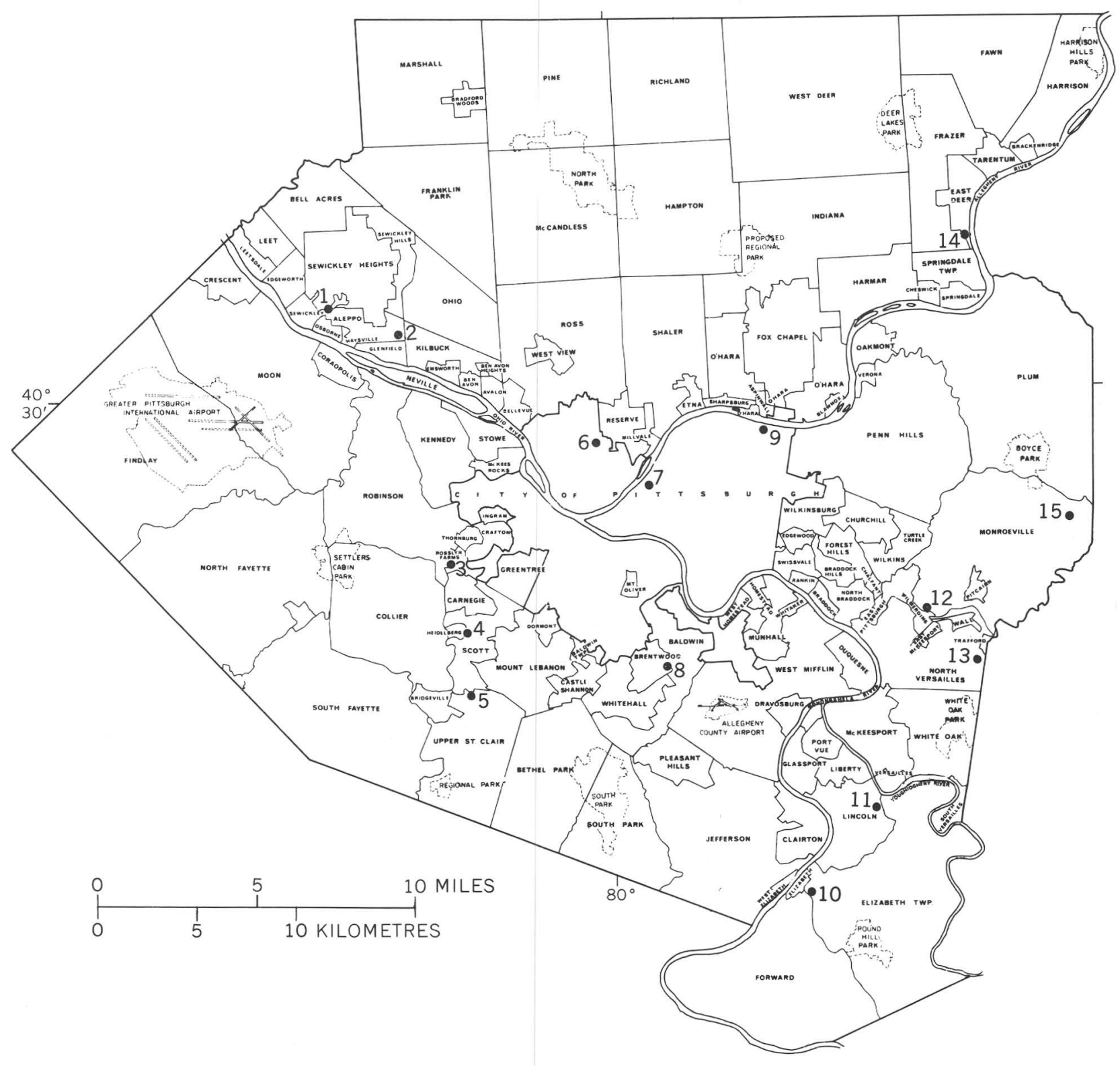

Figure 14.-Map of Allegheny County, showing locations of selected landslide localities. 
tive materials resulted in serious and recurring landslide problems (fig. 11; fig. 13; Hamel and Flint, 1969).

(3) Baldwin Road, Robinson Township, about 1/4 mile north of Penn-Lincoln Parkway, "Parkway West."-Along the southeast side of the apartment complex on the northwest side of Baldwin Road is a steep fill slope in which some slumping occurred. Brick walls of some units of the complex cracked, and slumping forced removal of back porches of several units. Additions to downspouts were made to direct water, a possible causative factor in the slumping, away from foundations. A concrete retaining wall between the lowest developed level and the second level was distressed (fig. 15). The Pittsburgh coal bed here is at or slightly below the level of the lowest buildings of the complex, and the coal has been mined out, according to information from the Pennsylvania Division of Mine Subsidence Regulation. Possible mine subsidence, soil creep, and landsliding, and the potential for lateral spreading under footings may have combined to make assurance of structural integrity more difficult here than elsewhere.

(4) Narrow ridge between Chartiers Creek and the Norfolk and Western Railway, Scott Township, just east of Borough of Heidelberg. - Surface cracks in this ridge are similar to but smaller than cracks on the slope at locality 10 and may also indicate slope failure (John Reynolds, oral commun., 1974). However, the top of the ridge is only about 30 feet above the Pittsburgh coal bed, mined out in this area, so sub-

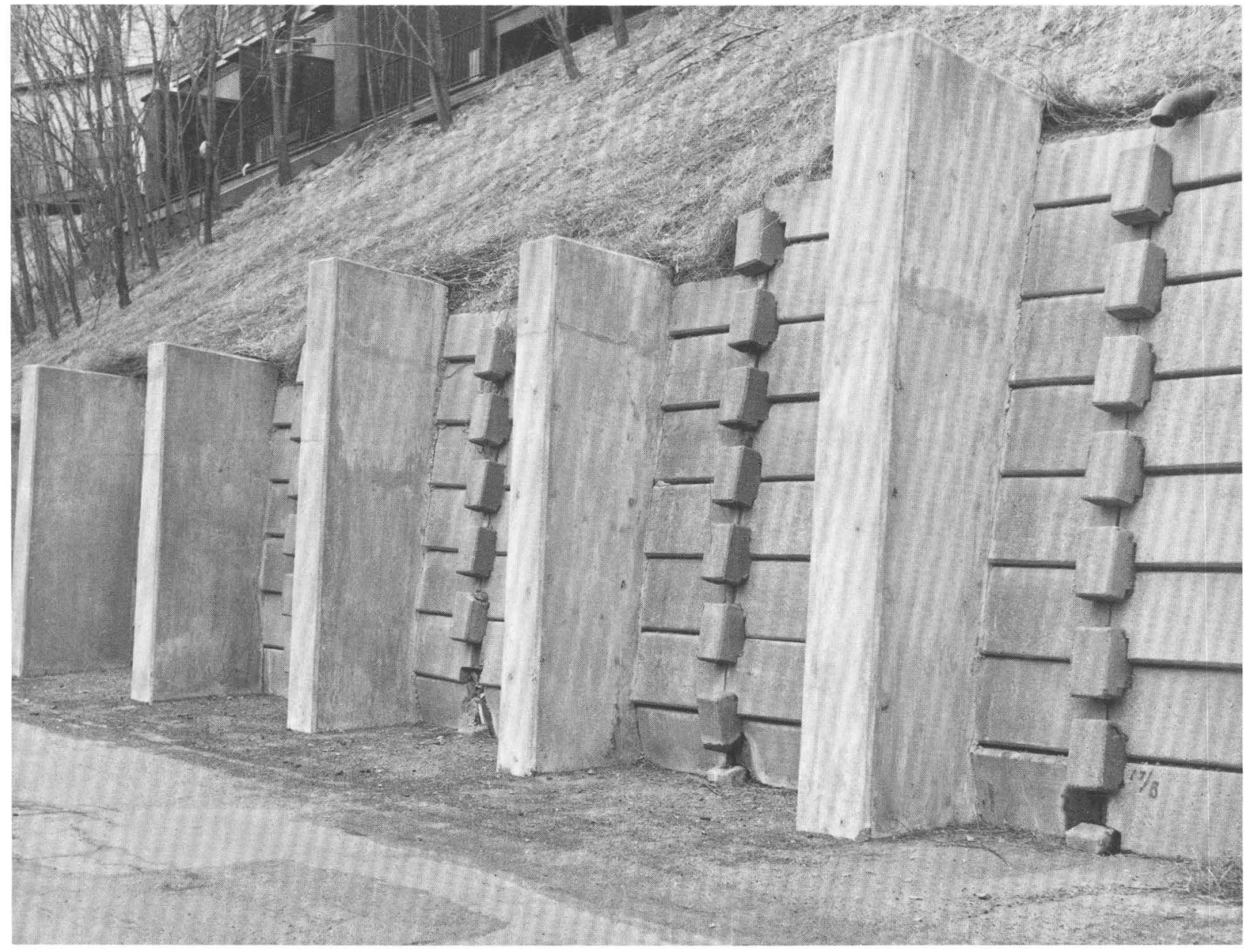

FIGURE 15.-Distressed concrete retaining wall near Baldwin Road, Robinson Township, which has missing key block at bottom of third segment from right. Vertical buttresses aid in repair effort. Note saplings leaning strongly downhill at left. Photographed in April 1975. 
sidence of the surface because of undermining may be responsible for these phenomena.

(5) Painters Run Road, Upper St. Clair Township, about 1/4. mile east of Bower Hill Road.-The landslide on the northeast side of the creek (fig. 10) formed in 1971 after a fill was placed to extend the backyard of the house at the top of the bluff. The fill failed shortly afterwards, and additional fill was placed. During tropical storm Agnes in 1972, the landslide mass moved down to the creek, leaving a bedrock face exposed. Since then, the fill on the flat above has slumped, forcing a change in the alinement of a fence. The rocks on which the slide formed are in the middle part of the Monongahela Group, about 100 feet above the Pittsburgh coal bed, which is exposed at road level on the south side of the road.

(6) Kilbuck Drive just opposite the Maintenance Office for Riverview Park, City of Pittsburgh.-The toe of a large landslide, very active in early 1974, encroached on the road (fig. 16).
The head of the landslide is near an apartment complex on the ridge above, and it can be viewed from the north end of the parking area of the complex. The lower half of the slope is underlain by red beds, and the upper slope is underlain by interlayered gray claystone and red beds. Evidence of distress to structures in the complex included wall cracks, and one pier out of plumb. Immediately south of the apartment complex is the scar of a very large 1949 landslide documented by Ackenheil (1954) .

(7) Bigelow Boulevard, City of Pittsburgh, in line with 24 th Street, southeast of Allegheny River.-This massive fill failure had its beginnings when the boulevard was constructed in 1896. Fill deposited then and later had a history of movement that culminated in late 1920 , when the toe encroached on the Pennsylvania Railroad (now Penn Central Transportation Company) yard at rates as fast as 12 inches per hour. More than 200,000 cubic yards of material was involved. When asked what could be done

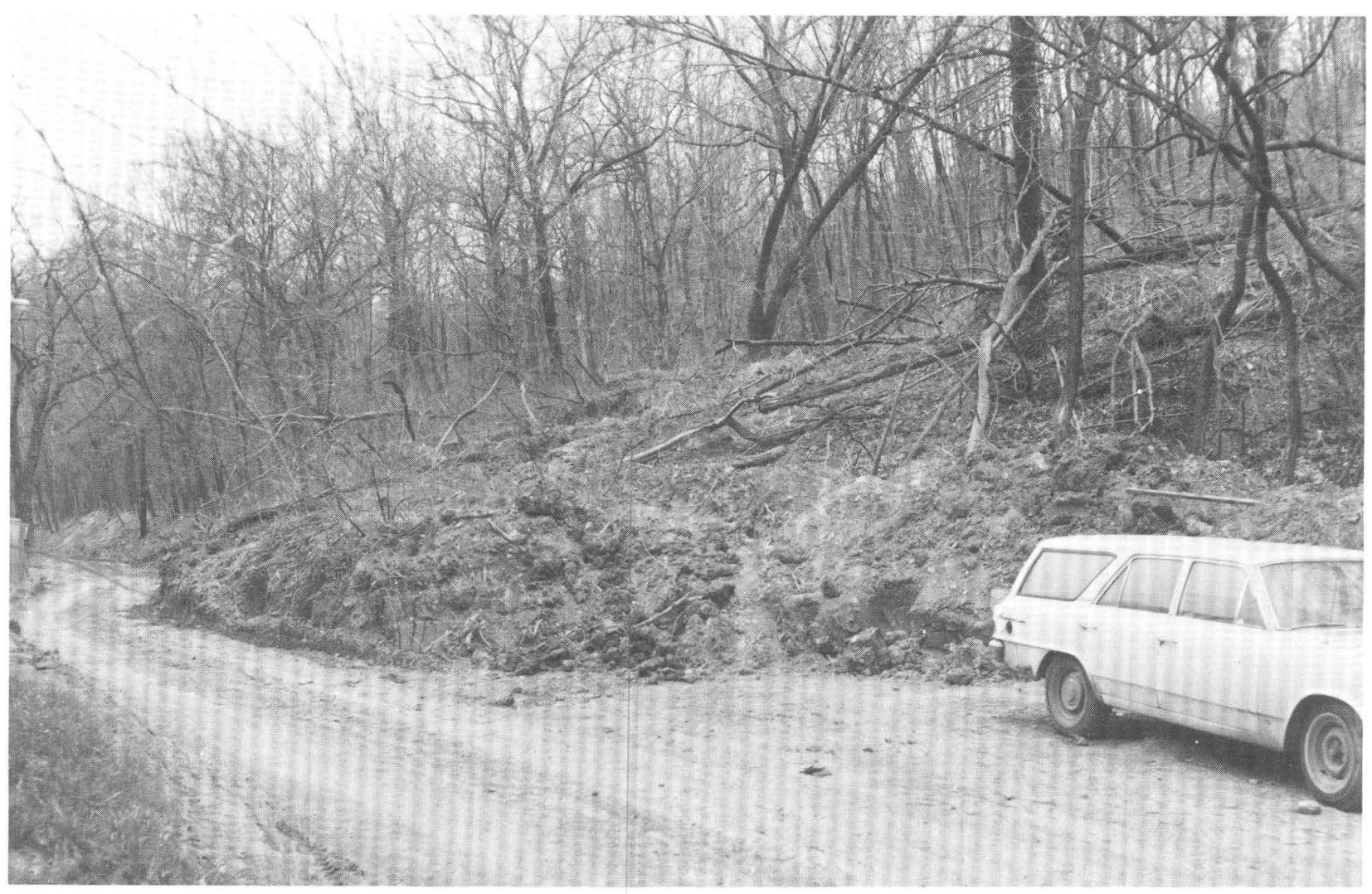

FIGURE 16.-Toe of landslide encroaches on Kilbuck Drive opposite park maintenance office adjacent to fence at left edge of picture. Car on right is parked at right edge of road, which was two lanes wide and straight before landsliding. Continuous excavation is required to keep road open. Photographed in April 1975. 
to remedy the landslide, General G. W. Goethals of Panama Canal fame is said to have answered, "let 'er slide" (Ackenheil, 1954).

(8) Lawnwood Avenue, Boroughs of Brentwood and Baldwin.-Failure after placing foundation footings on fill is well illustrated here where three houses have been destroyed and a fourth appears to be in danger (fig. 17). The first fill was placed across a narrow valley on the slope. The houses were built in the 1960's ; footings were placed in the old fill, and backyards were built up by emplacement of additional fill. Movement began shortly after the houses were completed, when the backyards slumped. The backyards were built up again, but further movement occurred, and by June 1972, two houses were so damaged that they were abandoned. The third house, on the east, was evacuated in February 1974, when the back wall began to collapse (fig. 8). The fourth house, on the west, had suffered no apparent structural damage and was still occupied in late 1974. How- ever, the side yard and part of the backyard had slumped away, exposing part of the foundation (fig. 8). Downslope movement in this area is not all recent, as is well indicated by large trees leaning strongly downhill a short distance to the west (fig. 8). The Pittsburgh coal bed has been mined out beneath this area, and mine drainage is evident at the foot of the slide. Lubrication and increased buoyancy from mine waters may be factors in the Lawnwood Avenue landslide (Craft, 1974).

(9) Brilliant Cut, City of Pittsburgh, about 1/2 mile east of Highland Park Bridge.-The massive failure of about 110,000 cubic yards of rock blocked the Pennsylvania Railroad (now Penn Central Transportation Company) tracks in 1941. Failure has been attributed to introduction of water through open joints, resulting in movement along a failure plane which had formed in red beds and gray shale (Ackenheil, 1954; Hamel, 1972). Although evidence of the landslide long since has been obscured, this

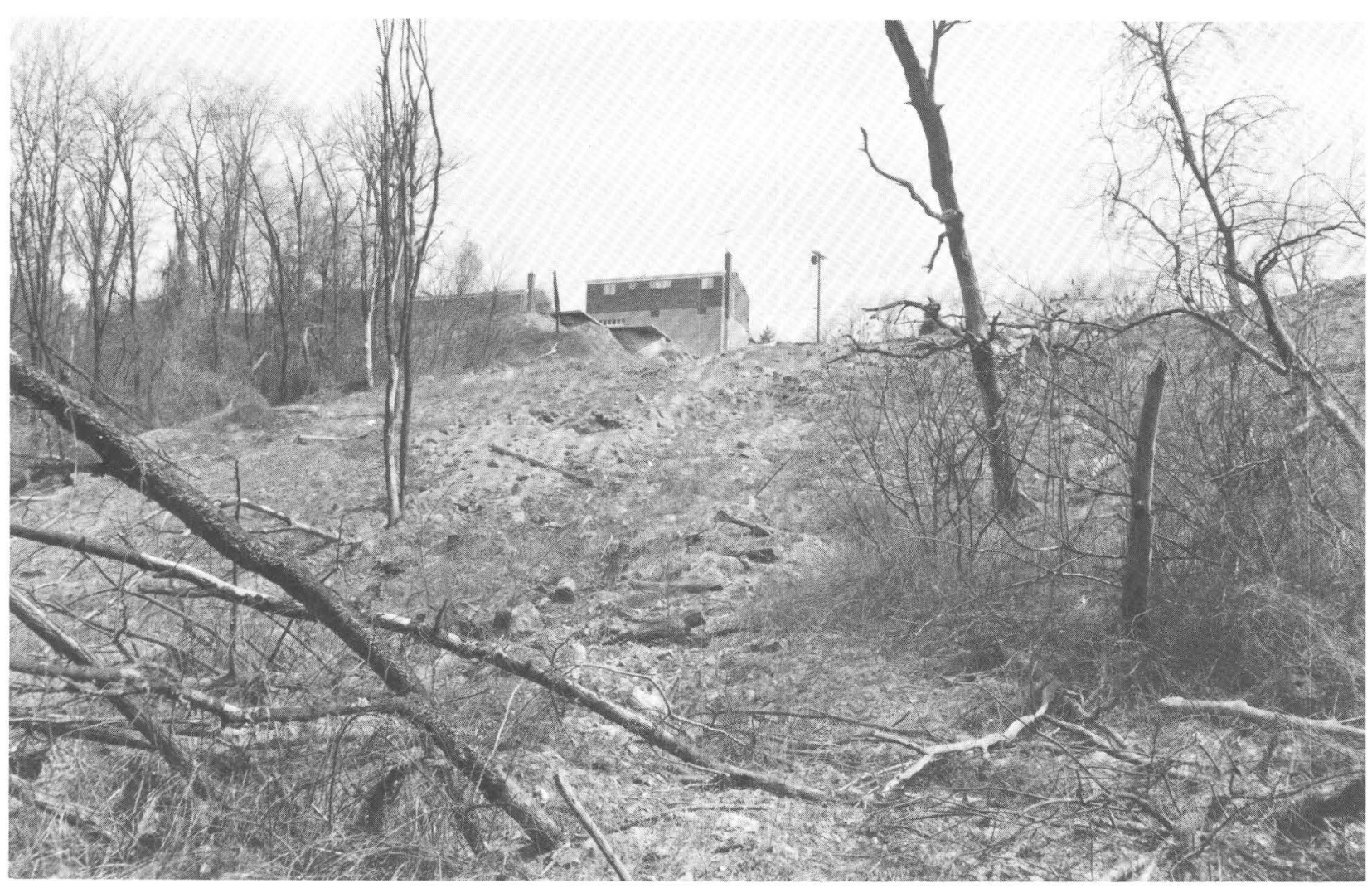

Figure 17.-Landslide on Lawnwood Avenue, Brentwood and Baldwin Boroughs, from base of slope. Fallen trees in foreground are in toe of landslide. House in center is in right background of figure 8. Clearly shown is undercutting of slabs in backyard of this house. Area to right of house was occupied by three houses destroyed by landsliding. Photographed in April 1975. 
locality remains one of the better exposures of this part of the rock sequence.

(10) Fallen Timber Run, Elizabeth Township, about 1/2 mile southeast of the Monongahela River.-Houses at the top of the slope on the northeast side of the valley may be in danger from a complex slope failure. In mid-1974, there was no conspicuous structural damage to any house, but at least one house appeared to be moving; the owner had to relevel appliances several times. Backyards made on fill have slumped, forming escarpments and cracks in soil. Cracks as much as 10 feet wide, 30 feet deep, and many tens of feet long, as shown in figure 12, have opened in soil and rock on the slope between the houses and the valley. Earth material was encroaching on buildings in the valley, and at the time of writing (1974), several governmental agencies were investigating this area; studies included periodic use of precision surveying instruments to measure displacements. Because the nature and extent of this landslide are not yet clearly known, the area is indicated on the companion map as a prehistoric landslide on which recent landslides have been superimposed. The area is underlain by rocks of the Casselman Formation.

(11) West Smithfield Road, Borough of Lincoln, 1/4 to 1 mile southwest of Boston.-Hummocky ground, characteristic of prehistoric landslides on red beds, is well developed on the northwest side of valley. Grapevines and tilted trees are common. A recent earthflow is well exposed on the south side of the road, near Boston (fig. 9).

(12) Russian Hill, Borough of Wilmerding, just northwest of intersection of Pennsylvania Highway 130 and Wilmerding Road.-Houses built many decades ago on a steep slope underlain by red beds were unaffected by their location until late winter 1971, when excavation upslope altered natural drainage (Kelley, 1971). Movement of red-bed soil damaged and forced abandonment of some houses. In 1974, damage on Laveen Street still was conspicuous.

(13) Intersection of U.S. Highway 30 and Pennsylvania Highway 48, North Versailles Township.-In 1968, shortly after the shopping center on the northeast corner was built, about 75,000 cubic yards of fill slumped into the valley, carrying away the eastern part of the parking lot. Attempts to rebuild the parking area have resulted in renewed movement. The base of the fill was on rocks of the Casselman Formation. Features of the landslide area include intermittently ponded water near its eastern edge.

(14) Glassmere vicinity, East Deer Township.-The very steep east-facing slope from the vicinity of the west end of the New Kensington bridge northward to Crawford Run has a long history of slope-stability problems, as is indicated by widespread prehistoric landslide deposits, at least one abandoned property near the bridge, and buckled and displaced retaining walls. The extremely heavy rains accompanying tropical storm Agnes, in June 1972, triggered further landslides that resulted in destruction of one house, damage to others, and temporary blocking of Freeport Road. Bedrock of the lower slopes largely is composed of red beds.

(15) Elliot Road, just north of the William Penn Highway, Borough of Monroeville, about 1 mile east of Pennsylvania Turnpike overpass. -Red beds weathered to an 8- to 15-foot-thick silty-clay soil are exposed in a shallow borrow pit. Beneath the soil, the red beds are weathered to a crumbly slippery mass. Deeply weathered gray and yellow-brown shales also are exposed. A small, recent landslide extends from the east end of the pit to the old William Penn Highway. This locality provides the interested observer with a good opportunity to examine types of material involved in many landslides in Allegheny County.

\section{GLOSSARY}

Alluvium.-A general term for unconsolidated fine- to coarse-grained sediment deposited during comparatively recent geologic time by running water in the bed of a river or stream, on a flood plain adjacent to a river or stream, or in related environments of deposition.

Anticline.-A fold of rock layers that is convex upward, opposite to the form of a syncline.

Bedrock.-A general term for the rock, usually solid, that underlies soil or other unconsolidated surficial material.

Clay.-A loose earthy aggregate of mineral or rock particles most of which are less than 
$1 / 256 \mathrm{~mm}$ in diameter. Commonly composed chiefly of clay minerals and quartz.

Claystone.-A rock composed of indurated clay.

Contact.-A boundary between different rock units.

Dip.-The angle by which the plane of rock layering (or other planar element, such as a joint) is inclined from the horizontal. Commonly expressed in degrees or in feet per mile.

Fault.-An earth fracture along which materials on one side have been displaced relative to those on the opposing side. Displacement can range in scale from inches to many miles.

Formation.-The basic rock-stratigraphic unit in the local classification of rocks. Commonly of considerable thickness and lateral extent and commonly shows distinct differences in rock type or proportions of rock types from formations immediately above and below.

Geomorphology.-The definition and description of the configuration of the Earth's surface.

Group.-A major rock-stratigraphic unit consisting wholly of two or more contiguous or associated formations having significant rock features in common.

Indurated.-Descriptive of rock material hardened by the action of heat, pressure, or the introduction of some cementing compound not commonly contained in the original material.

Joint.-A fracture or parting in a rock in which rock on one side has not been displaced relative to rock on the opposing side. Usually planar or gently curved. Joints often occur in parallel sets in which spacing between joints is more or less regular. Spacing between joints varies widely in different rock types.

Limestone.-A rock consisting of more than 50 percent calcium carbonate, primarily in the form of the mineral calcite.

Member.-A subordinate rock-stratigraphic unit constituting some specially developed part of a formation. Commonly of moderate lateral extent and appreciably thinner than the formation of which the member is a part.
Mineral.-A naturally formed inorganic compound that has either a definite chemical composition or a composition that ranges between definite limits and that has usual$l y$, a characteristic crystal form.

Permeability.-In rocks and soil, the capacity to transmit water. The greater this capacity, the greater the permeability.

Rock.-Any naturally formed, consolidated or unconsolidated (loose) material generally composed of two or more minerals, occasionally of one mineral.

Sand.-A loose aggregate of mineral or rock particles, most of which range from $1 / 16$ $\mathrm{mm}$ to $2 \mathrm{~mm}$ in diameter. The mo t common mineral in sand is quartz.

Sandstone.-A rock composed of indurated sand.

Shale.-In usage common to the area, shale is moderately well indurated rock which is composed mostly of clay and silt-sized particles, which commonly is thinly or very thinly layered, and which commonly breaks down upon weathering to platy fragments oriented parallel or subparallel to rock layering.

Silt.-A loose aggregate of mineral or rock particles, most of which range from $1 / 256$ to $1 / 16 \mathrm{~mm}$ in diameter.

Siltstone.-A rock composed of indurated silt.

Stratigraphic.-Adjective descriptive of geologic features and concepts related to stratigraphy.

Stratigraphy.-The definition and description of major and minor natural divisions in layered rocks, such as groups, formaticns, and members.

Surficial deposits.-Unconsolidated or weakly consolidated earth materials that rest on bedrock.

Syncline.-A fold of rock layers that is concave upward. For example. in cross section, a tightly folded syncline would have the form of the letter $U$.

Terrace deposit.-Alluvial deposits on re'atively level, commonly bench-shaped surfanes adjacent to river and stream valleys, generally at altitudes well above those reached by historic floods. Terrace alluvium. 


\section{REFERENCES CITED}

Ackenheil, A. C., 1954, A soil mechanics and engineering geology analysis of landslides in the area of Pittsburgh, Pennsylvania: Pittsburgh, Pa., Univ. Pittsburgh, Ph.D. dissert., 121 p. (Ann Arbor, Michigan, Univ. Microfilms, Pub. no. 9957, 1962.)

Ackenheil, A. C., and Associates, Inc., 1968, Mining and physiographic study, Allegheny County, Pennsylvania for the Board of County Commissioners: Pittsburgh, Pa., 45 p., maps.

Briggs, R. P., 1974, Map of overdip slopes that can affect landsliding in Allegheny County, Pennsylvania: U.S. Geol. Survey Misc. Field Studies Map MF-543.

Craft, J. L., 1974, Is a geologic evaluation of a development site needed?: Pennsylvania Geology, v. 5, no. 3, p. 2-5.

Eckel, E. B., ed., 1958, Landslides and engineering practice: Natl. Research Council, Highway Research Board Spec. Rept. 29 (Natl. Acad. Sci.-Natl. Research Council Pub. 544), 232 p.

Fisher, S. P., Fanaff, A. S., and Picking, L. W., 1968, Landslides of southeastern Ohio: Ohio Jour. Sci., v. 68, no. 2 , p. $65-80$.

Hamel, J. V., 1970, Stability of slopes in soft altered rocks: Pittsburgh, Pa., Univ. Pittsburgh, Ph.D. dissert., $305 \mathrm{p}$.

1972, The slide at Brilliant cut, in Stability of rock slopes-Proceedings of the 13th Symposium on Rock Mechanics, Urbana, Illinois, 1971: New York, Am. Inst., Mining Metall., Petroleum Engineers, Soc. Mining Engineers, p. 487-510.

Hamel, J. V., and Flint, N. K., 1969, Analysis and design of highway cuts in rock: a slope stability study on Interstate Routes 279 and 79 near Pittsburgh, Pennsylvania: Pennsylvania Dept. Highways Research Proj. no. 41472, $130 \mathrm{p}$.

1972, Failure of colluvial slope: Am. Soc. Civil Engineers, Soil Mechanics and Foundations Div. Jour., v. 98, no. SM2, p. 167-180.

Kelley, D. R., 1971, Wilmerding landslide, cooperative Pennsylvania Geological Survey emergency effort: Pennsylvania Geology, v. 2, no. 3, p. 11-12.

Kohl, W. R., and Briggs, R. P., 1975, Map of rock types in bedrock of Allegheny County, Pennsylvania: U.S. Geol. Survey Misc. Field Studies Map MF-685A.

Myers, C. K., 1935, The red beds of the Pittsburgh quadrangle: Pittsburgh, Pa., Univ. Pittsburgh, Ph.D. dissert., $56 \mathrm{p}$.

Nilsen, T. H., 1972, Preliminary photointerpretation map of landslide and other surficial deposits of parts of the Los Gatos, Morgan Hill, Gilroy Hot Springs, Pacheco Pass, Quien Sabe, and Holl : ster 15-minute quadrangles, Santa Clara County, California: U.S. Geol. Survey Misc. Field Studies Map MF-416, 2 sheets, scale 1:62,500.

Philbrick, S. S., 1959, Engineering geology of the Pittsburgh area, in Geol. Soc. America, Guidebook for field trips, Pittsburgh Meeting, 1959-Field Trip no. 6 : p. 189-203.

1960, Cyclic sediments and enginsering geology: Internat. Geol. Cong., 21st, Copenhag’n, 1960, Rept., pt. 20, p. 49-63.

Pomeroy, J. S., 1974, Landslide susceptibility map of the Pittsburgh West 71/2-minute quadrangle, Allegheny County, Pennsylvania: U.S. Geol. Survey open-file report 74-228, $16 \mathrm{p.}, 1 \mathrm{pl} ., 7$ figs.

Pomeroy, J. S., and Davies, W. E., 1975, Map of susceptibility to landsliding, Allegheny County, Pennsylvania: U.S. Geol. Survey Misc. Field Studies Map MF-685B [in press].

Sharpe, C. F. S., 1938, Landslides and related phenomena; a study of mass-movements of soil and rock: New York, Columbia Univ. Press, 136 p. [reprinted 1960, Paterson, N.J., Pageant Books].

Subitzky, Seymour, 1975a, A summary of behavior of the hydrologic regime as related to land-use characteristics, Allegheny County, Penrsylvania: U.S. Geol. Survey Misc. Field Studies Map MF-641A [in press].

1975b, Hydrogeologic framework and generalized shallow ground-water circulation system, Allegheny County, Pennsylvania: U.S. Geol. Survey Misc. Field Studies Map MF-641B [in press].

- 1975c, Heavy storm precipitation and related mass movement, Allegheny County, Pennsylvania: U.S. Geol. Survey Misc. Field Studies Map MF641D [in press].

U.S. Soil Conservation Service, 1973a, Volume 1, Soil survey maps for Allegheny County, Pennsylvania: Washington, D.C., U.S. Govt. Printing Office, p. 1-7, 243 p. of maps.

1973b, Volume 2, Soil survey interpretations for Allegheny County, Pennsylvania: Washington, D.C., U.S. Govt. Printing Office, p. 1-120, G1-G7.

Wagner, W. R., Heyman, Louis, Gray, R. E., Belz, D. J., Lund, Richard, Cate, A. S., and Edgerton, C. D., 1970, Geology of the Pittsburgh area: Pennsylvania Geol. Survey, 4th ser., Gen. Geol. Rent. G 59, 145 p.

Winters, D. M., 1972, Pittsburgh red bed -Stratigraphy and slope stability in Allegheny County, Pennsylvania: Pittsburgh, Pa., Univ. Pittsburgh, Ph.D. dissert., $49 \mathrm{p}$. 

